This is a self-archived - parallel published version of this article in the publication archive of the University of Vaasa. It might differ from the original.

\title{
Mediating role of open innovation between the relationship of Blue ocean strategy and innovation performance, a study of Malaysian industry
}

Author(s): Shafiq, Muhammad; Tasmin, Rosmaini; Takala, Josu; Qureshi, Muhammad Imran; Rashid, Mehwish

Title: Mediating role of open innovation between the relationship of Blue ocean strategy and innovation performance, a study of Malaysian industry

Year: $\quad 2018$

Version: Publisher's PDF

Copyright (C) Authors, published by Science Publishing Corporation, Creative Commons Attribution (CC BY) License

Please cite the original version:

Shafiq, M., Tasmin, R., Takala, J., Qureshi, M. I., \& Rashid, M., (2018). Mediating role of open innovation between the relationship of Blue ocean strategy and innovation performance, a study of Malaysian industry. International Journal of Engineering and Technology 7(2.29), 1076-1081. http://dx.doi.org/10.14419/ijet.v7i2.29.14316 


$\xi=-1$

\title{
Mediating Role of Open Innovation Between the Relationship of Blue Ocean Strategy and Innovation Performance, a Study of Malaysian Industry
}

\author{
Muhammad Shafiq ${ }^{1 *}$, Rosmaini Tasmin², Josu Takala ${ }^{3}$, Muhammad Imran Qureshi ${ }^{4}$, Mehwish Rashid ${ }^{1}$ \\ ${ }^{1}$ phd Scholar, Faculty Of Technology Management And Business, Universti Tun Hussein Onn Malaysia, Johor Malaysia. \\ ${ }^{2}$ Associate Professor, Faculty Of Technology Management And Business, Universiti Tun Hussein Onn Malaysia, Johor Malaysia. \\ ${ }^{3}$ Professor, University Of Vaasa, Finland \\ ${ }^{4}$ Senior Lecturer, Uni KL, MITEC, Johor, Malaysia \\ *Corresponding Author E-Mail: Consult.Shafiq@Gmail.Com
}

\begin{abstract}
This paper presents the introduction, literature review and methodology part of a bigger research work. Blue ocean strategy, open innovation strategy and innovation performance are the main constructs of this study. In the start after the introduction of problem of innovation performance and discussion of Malaysian industries specifically, Government linked companies is presented. Then variables of the study are discussed in detail. Then relationship of these variables are discussed, and the mediating variable of innovation strategy is presented. Relationship of these different variables are established from previous literature. In the end, theoretical framework is displayed and hypothesis are created for this study. Methodology and conclusion are also discussed. A self-administered questionnaire for Kim \& Mauborgne's Blue ocean strategy's five characteristics is developed. While already established questionnaires are used for other two variables of innovation strategy and innovation performance. Results and discussion section presents the reliability, correlation and regression analysis of the pilot study, performed in Malaysian industry. In the end, possible future work of the study is elaborated.
\end{abstract}

Keywords: Inbound Innovation; Outbound Open Motivation; Blue Ocean Strategy; Innovation Performance; Malaysian Industries

\section{Introduction}

Despite government intentions and stress on innovation strategy, the 2016 Global Innovation Index shows Malaysia's continuous slide from 32nd rank in 2012 to 36 th in 2016 in the world: some distance behind its international and regional competitors e.g. Singapore [1]. Over a series of Malaysia Plans, the country's government has set out its aspirations to join the world's leading economic nations by 2020, and recognizes at the highest levels that the national innovation environment will need continued focus and investment in order to achieve this goal [2]. To be effective, strategies to promote innovation must reflect the ways in which innovation takes place today.

In Malaysian industry, both government linked organizations and private industry contribute to national growth. Government Linked Companies are very important in Malaysian economy because of workforce and market share. This research include the list of 250 Malaysian Government Linked Companies [GLC's] which contribute $36 \%$ in Bursa Malaysia and $54 \%$ in KL composite index. These GLC's are taken from Auditor General Report of Malaysia. Moreover, manufacturing and services organizations in Malaysia's FMM2017 are also part of this study. It is expected that this research will contribute significantly to Malaysian economy.

Various approaches and techniques have created complexities for organizations as stated by, [3] as Red oceans of competitive industries, and blue oceans of uncontested markets and industries. It becomes more complex as there are different innovation strategies [open, close] available as the importance of externally coordinated innovation and internal bound close innovation is frequently discussed in literature [4]. It makes it interesting to study innovation performance of Malaysian industry with relation to Blue ocean strategy as the modern business strategy.

Recently, [5] also asked to investigate Kim \& Mauborgne claim of non-destructive creation in blue ocean strategy as this is very important for governments to have economic growth by having non-destructive creation. Moreover, $14 \%$ Blue ocean launces provided $38 \%$ revenue while $61 \%$ profit impact, in comparison to $86 \%$ Red ocean launches provided $62 \%$ revenue and $39 \%$ profit impact [6]. Therefore it is important to investigate innovation performance of Malaysian industries, and impact of Blue Ocean strategy on innovation performance, a recent effort by authors was already a small step in this direction [7]. And mediating role of organizational open strategy between BOS and Innovation performance is also very important to research. Though there have been works on mediation of open innovation in other business strategies [8] but there has not been any significant quantitative research, performed for mediating role of open innovation on the relationship of Blue ocean strategy and innovation performance in Malaysian industries.

The objective of the research is to investigate and analyze the relationship of blue ocean strategy and innovation performance. And how innovation strategies [inbound collaboration, outbound collaboration] mediate the relationship of Blue Ocean strategy and innovation performance. 


\section{Literature review}

\subsection{Blue Ocean Strategy}

[9]shaked the strategy research field with Blue ocean strategy, saying, the success for pattern for today's organization is making the competion irrelevant. Blue Ocean Strategy provides a reconstructionist view from traditional competitive and resourcebased theories [6]. They claimed that Blue Ocean strategy is "a consistent pattern of strategic thinking behind the creation of new markets and industries where demand is created rather than fought for and the rule of competition is irrelevant" [6]. As, ccorporate strategy has not come out of its military basis, as titles of 'headquarters', 'troops' 'officers' 'front lines' display. Fighting and threatening with the competitors is centric to strategies. It is like a battle ground. So the opponents also involve in tit for tat strategies, so innovation takes a backseat. [6] reiterate that heads on competition among rivals squeeze profits in Red Ocean of bleeding organizations.

Blue Ocean rejects Porter's well discussed trade-off between differentiation and cost, BOS emphasize on value innovation. It does not advocate for technical advancement, rather focus on brand development as described [10]. There have been some researches on its implementation, concentrating its four action framework [Eliminate, Reduce, Raise,Create], moreover six paths of Blue Ocean strategy consisting of looking across alternative industry, strategic groups within industry, looking across chain of buyers, comlementary services and products, functional or emotional appeal and looking across time [6], and used by [11]. It has attracted interest of researchers all over the world, as they tried to explore Blue Ocean strategy for implemention in all over the world [7, 10-14]. The Malaysian government itself has taken alot of interest in Blue Ocean strategy, and in process of its successful implementation in Malaysia [15].

In the past research, it was considered that precious and exceptional resources give competitive edge to organization but according to Blue Ocean strategy, organizations must see ahead of dwindling resources and vicious competition for profitability [16].

Table 1: Red Ocean versus Blue Ocean Strategy [6] \begin{tabular}{|l|l}
\hline Red Ocean Strategy & Blue Ocean Strategy \\
\hline
\end{tabular} $\begin{array}{ll}\text { Compete in existing market space. } & \text { Create uncontested market space. }\end{array}$ \begin{tabular}{|l|l}
\hline Beat the competition. & Make the competition irrelevant.
\end{tabular} $\begin{array}{ll}\text { Exploit existing demand. } & \text { Create and capture new demand. }\end{array}$

\begin{tabular}{l|l|l}
\hline Make the value-cost trade-off. & Break the value-cost trade-off.
\end{tabular}

\begin{tabular}{ll}
\hline Align the whole system of a firm's & Align the whole system of a firm's
\end{tabular} activities with its strategic choice activities in pursuit of differentia\begin{tabular}{l|l} 
of differentiation or low cost & tion and low cost.
\end{tabular}

According to Blue Ocean strategy, triumph is making competition irrelevant, not just being in war with other organizations in the market or industry. And Blue Ocean creates the uncontested market space by value innovation. Value Innovation does not go for fighting with other organizations for market share but actually explores new markets and innovates values both for customers and the organization itself [6]. As claimed to study thirty of last century industries, stressing that strategic moves were the main ingredient for wealth creation neither the organizations, nor the industry.

[6] present four action framework to develop value innovation for both customers and organization, these four actions are Eliminate, Reduce, Create and Raise [17]. The mentioned four questions help to apply four action framework. Which of the factors that the industry takes for granted should be eliminated? Which factors should be reduced well below the industry's standard? Which factors should be raised well above the industry's standard? Which factors should be created that the industry has never offered? Moreover, Strategic moves are set of managerial activities and verdicts leading to a new creation of market. [6] claim to study 150 strategic moves from these thirty industries to understand the creation pattern of blue oceans and increase profitability. Strategic moves are the actions which open new markets with unique products or services. Strategic move basically creates new market of broad customers. Comparatively, competition is focused in existing market in red ocean strategy [18]. Blue ocean strategy has six main principles, to formulate and implement in any firm. Four of these are formulation principles; 1 . Reconstruct market boundaries, 2. Focus on the big picture not numbers, 3. Reach beyond existing demand, 4 . Get the strategic sequence right, while two are execution principles. 5. Overcome key organizational hurdles, 6. Build execution into strategy.

Red oceans demonstrate all the industries in existence today while Blue oceans represent the nonexistent industries. Organizations compete and leave their competitors behind to get greater pie of market demand. Profits and growth reduce because of crowded market. Untouched market space are accessed, new demands are explored, and new opportunities are created in Blue Ocean strategy. According to [6] ,Red oceans will always exist, and matter but Blue oceans have got to be created to get high performance. Blue oceans exist from years and centuries, which is a set pattern of strategic moves for organizational success which was not focused by strategy literature as it was dedicated on Red oceans of competition [19]. There have been many recent studies on empirical research, measurement tools and other aspects of Blue ocean strategies [17] which signifies the importance of this strategy. Five basic pillars or dimensions of Blue ocean strategy as mentioned by $[7,20]$ as adapted from [6] can be summarized as; 1 . Creating uncontested market space2. Making the competition irrelevant 3. Creating and capturing new demand 4. Breaking the value-cost trade-offs.5. Achieving differentiation \& low cost. Blue ocean shift [15] has highlighted the presence and implementation of BOS in Malaysia.

\subsection{Innovation Strategies}

Innovation is important for competitive advantage and success of organization. All organizations need innovation to enhance market share [21]. Organizations get motivation because of internationalization and competition for increase of innovation for competitive edge as stated by [22]. Firms have to innovate systematically with multiple strategies to have competitive edge [4 8]. In Forbes 100 list of last century, sixty one companies even do not exist while there are eighty two new entrants [23]. This describes innovation strategies require more attention. To explain systematically the innovation strategies [24] attempted. In this research, inbound and outbound open innovations are categorized as innovation strategies [25].

Open innovation has been one of the most iteratively discussed topic in management research in last ten years [26]. The present literature discusses construct of open innovation differently. It is sometimes associated with the different number of external sources involved for innovation [27], while few define it as disclosing previously covered ideas of organization [28]. Different forms of openness are described here, mainly as inbound and outbound open innovation. In this study, we will take both dimensions of open innovation, focus on external relationships and cooperation for innovation.

1. Inbound Open Innovation look for getting skills and expertise of the other organization for improving own innovation capabilities.

2. Outbound Open Innovation focus on financial gains through collaborations with other organizations.

Organization must possess different competencies especially in research and technology for its success. According to [29], there is commercial and financial risk is involved because of high expenditures and collaboration with an external organization. It requires to control and manage this process all the way from goals, partner selection and roles and responsibilities.

\subsection{Innovation Performance}

Organizational innovation performance is found by its activities of innovation, such as new services, new products, and number of patents as stated by [30]. Innovation performance captures unwar- 
ranted domains of organization's competitive advantage. Product innovation is seen an important way to give competitive advantage, and sustainability of organizations. The capability of an organization to develop new products and services is known as vibran ability [31]. Long ago, management researchers have recognized that companies gain and sustain competitive advantage due to the ability to renew, integrate and expand their existing competencies and continuously develop new capabilities [32]. Product innovation has been viewed in this context as an important mechanism through which organizations modify and establish competencies that are central for staying competitive within the fast-changing business environment [31]. Innovation performance in this study is measured by using, [21] scale, who use six questions to measure innovation performance. These are the innovation performance parameters, 1 . New products 2 .New services 3 .New methods of production 4 . Opening new markets 5 . New sources of supply 6 New ways of organizing

\section{Theoretical framework}

\subsection{Relationship between Blue Ocean Strategy with In- novation Strategies and Innovation Performance}

The relationship of strategy with innovation is discussed by $[4,31]$. Organizations having, high risk-taking trend to innovations, increase their competitive advantage is claimed by [33]. It is highlighted that there are differences between innovative and noninnovative firms as riskiness influence innovative capability positively [34]. An innovation strategy should be consistent to mission, vision, and strategies. The need of organizations in hypercompetitive markets to innovate and communicate require to adopt specialized generic strategies to reach out to customers differently and to gain competitive advantage [8,31,34]. No advantage is sustainable on a prolonged basis as the competing organizations will eventually imitate the product. Supportively, the primary purpose of an organization's existence is not only to exist but also to thrive. Sustainability, therefore, can only be obtained while comparing both the present and the future [10].

According to [23], sustainable competitive advantage will originate from cooperated work and collaborations of organizations, [35] warn that aloof organization will not succeed in future, organizations have to use collaborative strategy to mutually produce new products. It has been discussed that the possibilities of an organization may create a unique new idea but to bring it to market it collaborate with another firm to get commercial success. Despite the fact that both product and process innovation have a positive effect on business performance [36], the understanding of the external market conditions or characteristics under which these two different forms of innovation more or less beneficial is limited Product innovation no longer offers sufficient competitive advantage in differentiating successful companies [37]. Competitors are quickly able to copy innovations, product life cycles are becoming shorter and competitors from low wage countries have considerable cost and price advantages. Hence, companies consider business model innovation as an opportunity to build sustainable competitive advantage [3]. Outsourcing decisions are an important aspect of most firms' overall strategic plans and managers should review their make-buy policies accordingly [38]. It is suggested by [39] that a company is necessarily linked to other organizations, and should not be regarded as a standalone entity.

\subsection{Relationship between Innovation Strategy and In- novation Performance}

[21] in his work, suggested to explore the internal and external factors of innovation. Previously, companies pursued to improve their performance by using new strategies. Companies have to improve their financial performance through new technologies and fresh ideas. Thus, they build a strong relationship between innovation and their financial performance [40]. In open innovation focus shifts from the innovation itself to the search for novel knowledge and to the means of applying knowledge [41]. It is necessary to evaluate and compare the impact of different strategies on innovation performance [42]. Organization still may not prefer open innovation because it can reduce competitive edge in red oceans of competition [42]. Both direct and indirect ties can have positive impacts on innovation input and performance [43].

The return generated from innovation is the result of the interaction between business environment and firms' innovation strategies and capabilities. This is why our research studies innovations and innovation performance in different innovation strategies, employed in Blue Ocean business environments. As relationship of BOS and innovation performance [7] is already established using these BOS dimensions. As highlighted the need to analyze open-source innovation to be operationalized to enhance the innovation performance in future. [44], also stress the need to explore the relationship between open innovation strategies and innovation performance. In the light of Resource Based Theory, successful innovation strategies could deliver superior performance as innovation delivers value to customers [45], that makes it mandatory to study relationship of blue ocean strategy, innovation strategy and innovation performance. In light of all above discussions in introduction and literature review, below is research framework.

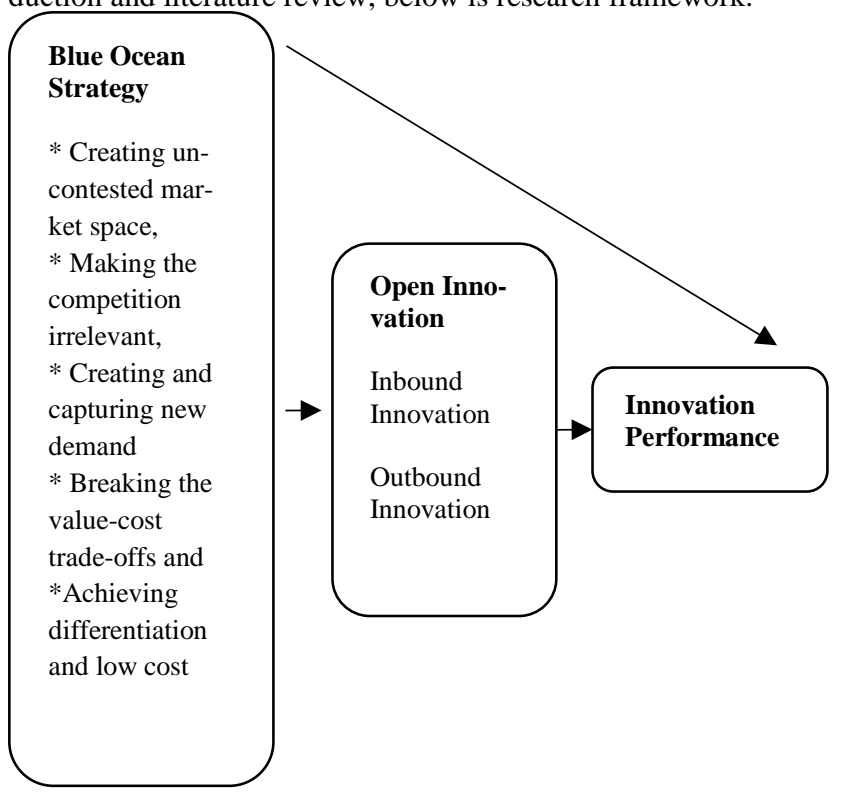

Fig. 1: Model of the Study

\subsection{Hypothesis of study}

Following hypothesis are formulated on the basis of theoretical framework of the study;

1. BOS has a positive relationship with innovation performance.

2. BOS has a positive relationship with innovation [outbound, inbound] strategy.

3. Innovation strategy [outbound, inbound] has a positive relationship with innovation performance.

Innovation strategy [outbound, inbound] mediates the relationship between BOS and innovation performance.

\section{Methodology}

Blue ocean shift [15] has highlighted the presence and implementation of BOS in Malaysia. An initial study of the authors already published a work on the relationship of BOS and innovation performance [7]. This research is a quantitative study as data will be collected through established scale of $[46,47]$ for innovation strategy and [21] for innovation performance. While a scale is developed for BOS based on [6]. The items for each dimensions of 
BOS are presented in Annex A, at the end of the references. Pretesting of questionnaire has been performed by academics and industrial experts. This study shows the results of pilot testing performed in SPSS. Smart PLS will be used for SEM in this research for factor loadings for different dimensions of each variable of Blue ocean strategy and innovation strategies.

\section{Results and discussion}

This sections presents and describes the results of the study. The table 2.1 shows the results of the reliability of each scale.

It is clear that all the values are reliable [48], here special focus is on Blue ocean strategy scale, as results verify the work of authors [7].

Table 2: Reliability

\begin{tabular}{|l|l|l|}
\hline Variable Uncontested & $\begin{array}{l}\text { Number of } \\
\text { items }\end{array}$ & Reliability Value \\
\hline $\begin{array}{l}\text { BOS-Creating Competition } \\
\text { Market }\end{array}$ & 5 & 0.90 \\
\hline $\begin{array}{l}\text { BOS-Making Cost } \\
\text { Irrelevant }\end{array}$ & 9 & 0.86 \\
\hline BOS-Creating New Demand & 6 & 0.87 \\
\hline $\begin{array}{l}\text { BOS-Aligning Value } \\
\text { Tradeoff }\end{array}$ & 4 & 0.90 \\
\hline BOS-Differentiation \& Cost & 6 & 0.80 \\
\hline Inbound Innovation & 4 & 0.82 \\
\hline Outbound Innovation & 6 & 0.72 \\
\hline Innovation Performance & 0.90 \\
\hline
\end{tabular}

Correlation Table 3, represents the correlation between the variables.

Table 3: Correlation

\begin{tabular}{|l|l|l|l|l|l|l|l|l|}
\hline & $\begin{array}{l}\text { B- } \\
\text { CNUM }\end{array}$ & $\begin{array}{l}\text { B- } \\
\text { MCI }\end{array}$ & $\begin{array}{l}\text { B- } \\
\text { CND }\end{array}$ & $\begin{array}{l}\text { B- } \\
\text { AVCT }\end{array}$ & $\begin{array}{l}\text { B- } \\
\text { D\&C }\end{array}$ & IBI & OBI & IP \\
\hline $\begin{array}{l}\text { B- } \\
\text { CNUM }\end{array}$ & - & .6 & .5 & .3 & .4 & .5 & .3 & .7 \\
\hline B-MCI & .6 & - & .7 & .6 & .4 & .3 & .3 & .6 \\
\hline $\begin{array}{l}\text { B- } \\
\text { CND }\end{array}$ & .5 & .7 & - & .6 & .6 & .4 & .2 & .6 \\
\hline $\begin{array}{l}\text { B- } \\
\text { AVCT }\end{array}$ & .3 & .6 & .6 & - & .5 & .3 & .3 & .5 \\
\hline $\begin{array}{l}\text { B- } \\
\text { D\&C }\end{array}$ & .4 & .4 & .6 & .5 & - & .3 & .1 & .4 \\
\hline IBI & .5 & .3 & .4 & .3 & .3 & - & .5 & .6 \\
\hline OBI & .3 & .3 & .2 & .3 & .1 & .5 & - & .3 \\
\hline IP & .7 & .6 & .6 & .5 & .4 & .6 & .3 & - \\
\hline
\end{tabular}

The correlation table clearly mentions the relationship among all variables. Relationship is positive.

\section{Regression}

Table 4: Model Summary

\begin{tabular}{|c|c|c|c|c|c|}
\hline & $\mathrm{R}$ & $\mathrm{R} 2$ & Adjusted R & F Change & F Significant \\
\hline 1 & .76 & .59 & .54 & 12.2 & .00 \\
\hline 2 & .80 & .63 & .57 & 2.7 & .05 \\
\hline
\end{tabular}

1. BOS without Mediation

2. BOS with Mediation of OBIMeans and IBIMeans

Table 5: ANOVA
\begin{tabular}{|c|c|c|c|c|c|}
\hline Model & Sum Sq & df & Mean $^{2}$ & F & Sig \\
\hline 1 Reg & 19.9 & 6 & 3.3 & 12.2 & 0.00 \\
\hline Res & 13.8 & 51 & .27 & & \\
\hline Total & 33.8 & 57 & & & \\
\hline 2 Regr & 21.3 & 8 & 2.6 & 10.4 & 0.00 \\
\hline Res & 12.4 & 49 & .25 & & \\
\hline Total & 33.8 & 57 & & & \\
\hline
\end{tabular}

1. BOS without Mediation. 2. with Mediation OBI/IBI

\section{Conclusions and Future Works}

It is very important to investigate aforementioned very important relationship empirically as a very good research model is developed. Literature supports a positive relationship for Blue ocean business strategy and innovation strategies and innovation performance. Moreover literature also supports the mediating role of innovation strategy between BOS and Innovation performance. Our data is reliable, correlated and hypothesis are supported as Blue ocean strategy has positive impact on innovation performance, while mediation results are also significant.

It will also be very interesting in future to investigate the relationships of Blue ocean strategy with innovation types of radical and incremental. Another interesting plan of research is to investigate blue ocean strategy with innovation nature i.e. nondestructive. Authors work to quantify the impact of Blue ocean strategy's five dimensions on organizational performance at industry level is also in publication.

\section{References}

[1] Dutta S, Lanvin B, Wunsch-Vincent S. The global innovation index 2016: Winning with global innovation: Johnson Cornell University; 2016.

[2] FRSA MB, Reid B. Innovation, intangibles and integrated reporting: a pilot study of Malaysian SMEs. 2015.

[3] Casadesus-Masanell R, Ricart JE. From strategy to business models and onto tactics. Long range planning. 2010;43[2-3]:195-215.

[4] Shafiq M, Tasmin R. Linking Business Strategy with Organizational Innovation. Innovation and Management. 2016.

[5] Randall RM. W. Chan Kim and Renée Mauborgne dispel blue ocean myths. Strategy \& Leadership. 2015;43[2]:11-4.

[6] Kim WC, Mauborgne RA. Blue ocean strategy, expanded edition: How to create uncontested market space and make the competition irrelevant: Harvard business review Press; 2014.

[7] Shafiq M, Tasmin R, Takala J, Qureshi MI, Rashid M. RELATIONSHIP OF BLUE OCEAN STRATEGY AND INNOVATION PERFORMANCE, AN EMPIRICAL STUDY. 2017.

[8] Muhammad S, Rosmaini T, Mehwish R. Mediating Role of Innovation Strategy Between Porter's Red Ocean Strategy and Innovative Performance. Advanced Science Letters. 2017;23[9]:9239-42.

[9] Kim WC, Mauborgne R. Blue ocean strategy. California management review. 2005;47[3]:105-21.

[10] Vinayan G, Jayashree S, Marthandan G. Critical success factors of sustainable competitive advantage: A study in Malaysian manufacturing industries. international journal of business and management. 2012;7[22]:29.

[11] Butler C. Planning with blue ocean strategy in the United Arab Emirates. Strategic Change. 2008;17[5-6]:169-78.

[12] Radzi S, Yasin M, Zahari M, Abas R, Ahmat N, Ahmad-Ridzuan A Blue Ocean Strategy [BOS] and performance of four and five star hotels in Kuala Lumpur, Selangor and Putrajaya. Heritage, Culture and Society: Research agenda and best practices in the hospitality and tourism industry. 2016:207.

[13] Kim C, Yang KH, Kim J. A strategy for third-party logistics systems: A case analysis using the blue ocean strategy. Omega. 2008;36[4]:522-34.

[14] Bourletidis D. The strategic model of innovation clusters: Implementation of blue ocean strategy in a typical Greek region. Procedia-Social and Behavioral Sciences. 2014;148:645-52.

[15] Mauborgne R, Kim WC. Blue ocean shift: Macmillan; 2017.

[16] Morrish SC. Entrepreneurial marketing: a strategy for the twentyfirst century? Journal of Research in Marketing and Entrepreneurship. 2011;13[2]:110-9.

[17] Borgianni Y, Cascini G, Rotini F. Investigating the patterns of value-oriented innovations in blue ocean strategy. International Journal of Innovation Science. 2012;4[3]:123-42.

[18] Leavy B. A leader's guide to creating an innovation culture. Strategy \& Leadership. 2005;33[4]:38-45.

[19] Hollensen S. The Blue Ocean that disappeared-the case of Nintendo Wii. Journal of business strategy. 2013;34[5]:25-35.

[20] Omar AR, Tasmin R. Society Transformation and Social Development through University-Community Transformation Centre [UCTC] Via Universiti Tun Hussein Onn Malaysia Experience. Journal of Techno Social. 2015;7[2].

[21] Johannessen J-A, Olsen B, Lumpkin GT. Innovation as newness: what is new, how new, and new to whom? European Journal of innovation management. 2001;4[1]:20-31.

[22] Harris R, McAdam R, McCausland I, Reid R. Knowledge management as a source of innovation and competitive advantage 
for SMEs in peripheral regions. The International Journal of Entrepreneurship and Innovation. 2013;14[1]:49-61.

[23] Dasgupta S, Sanyal D. Bridge to the future: connect your strategie in an interconnected world. Foresight. 2009;11[1]:81-93.

[24] Garcia R, Calantone R. A critical look at technological innovation typology and innovativeness terminology: a literature review. Journal of product innovation management. 2002;19[2]:110-32.

[25] Urban GL, Von Hippel E. Lead user analyses for the developmen of new industrial products. Management science. 1988;34[5]:56982.

[26] West J, Gallagher S. Challenges of open innovation: the paradox of firm investment in open-source software. R\&d Management. 2006;36[3]:319-31.

[27] Laursen K, Salter A. Open for innovation: the role of openness in explaining innovation performance among UK manufacturing firms. Strategic management journal. 2006;27[2]:131-50.

[28] Henkel J. Selective revealing in open innovation processes: The case of embedded Linux. Research policy. 2006;35[7]:953-69.

[29] 29. Dodgson M, Gann D, Salter AJ. Think, play, do: Technology, innovation, and organization: Oxford University Press on Demand 2005 .

[30] Jiang X, Li Y. An empirical investigation of knowledge management and innovative performance: The case of alliances. Research Policy. 2009;38[2]:358-68.

[31] Lokshin B, Van Gils A, Bauer E. Crafting firm competencies to improve innovative performance. European Management Journal. 2009;27[3]:187-96.

[32] Teece DJ, Pisano G, Shuen A. Dynamic capabilities and strategic management. Knowledge and strategy: Elsevier; 1999. p. 77-115.

[33] Forrester RH. Capturing learning and applying knowledge: an investigation of the use of innovation teams in Japanese and American automotive firms. Journal of Business Research 2000;47[1]:35-45.

[34] Karabulut AT. Effects of innovation types on performance of manufacturing firms in Turkey. Procedia-Social and Behavioral Sciences. 2015; 195:1355-64

[35] Iansiti M, Levien R. The keystone advantage: what the new dynamics of business ecosystems mean for strategy, innovation, and sustainability: Harvard Business Press; 2004.

[36] Prajogo DI, Ahmed PK. The relationships between quality, innovation and business performance: An empirical study. International Journal of Business Performance Management 2007;9[4]:380-405.

[37] McGrath AE. The open secret: A new vision for natural theology: John Wiley \& Sons; 2011

[38] Fine $\mathrm{CH}$, Whitney $\mathrm{DE}$. Is the make-buy decision process a core competence? 2002

[39] Afuah A. Dynamic boundaries of the firm: are firms better off being vertically integrated in the face of a technological change? Academy of Management journal. 2001;44[6]:1211-28.

[40] Ezzia F, Jarbouib A. ¿ Afecta la estrategia de innovación a rendimiento financiero, social y ambiental? Journal of Economics, Finance and Administrative Science. 2016;21[40]:14-24

[41] Gobbo Jr JA, Olsson A. The transformation between exploration and exploitation applied to inventors of packaging innovations. Technovation. 2010;30[5-6]:322-31.

[42] Enkel E, Gassmann O, Chesbrough H. Open R\&D and open innovation: exploring the phenomenon. R\&d Management. 2009;39[4]:311-6

[43] Lichtenthaler U, Lichtenthaler E. A capability-based framework for open innovation: Complementing absorptive capacity. Journal of management studies. 2009;46[8]:1315-38.

[44] Leminen S, Nyström A-G, Westerlund M, Kortelainen MJ. The effect of network structure on radical innovation in living labs. Journal of Business \& Industrial Marketing. 2016;31[6]:743-57.

[45] Prajogo DI. The strategic fit between innovation strategies and business environment in delivering business performance. International Journal of Production Economics. 2016;171:241-9.

[46] Sisodiya SR. The effect of open innovation on new product development success: the moderation of interfirm relational knowledge stores and social network characteristics: Washington State University; 2008

[47] Lichtenthaler U. Outbound open innovation and its effect on firm performance: examining environmental influences. R\&d Management. 2009;39[4]:317-30.

[48] Nunnally JC, Bernstein IH. Psychometric theory. 1978.

\section{Annex A}

\section{Questionnaire for Blue Ocean Strategy}

This questionnaire is developed by authors to measure Blue Ocean Strategy. All the items are adapted from Blue Ocean Strategy Book by Kim \& Mauborgne [2005]. This questionaire is validated by academics and industrialists. It is a reliable instrument.

\section{Creating Uncontested Market Space}

My organization looks across other industries to explore alternative markets.

My organization looks across different strategic groups within industry to explore new markets.

My organization looks across complementary products offering to explore new market

My organization looks across complementary service offering to explore new market

My organization reconsiders emotional orientation of its industry.

My organization reconsiders functional orientation of its industry.

My organization tries to create new markets by enhancing product lines

My organization creates new uncontested markets.

\section{Making the competition irrelevant}

My organization makes competition irrelevant with other organizations.

My organization tends to invest in the area where already very few competitors

My organization provides innovative products to lock out competitors.

My organization provides innovative services to lock out competitors.

My organization enjoys profits by increase of sales.

\section{Creating and Capturing New Demand}

My organization participates in shaping external trends over time to create new demand

My organization has a good tagline to attract new customers

My organization focuses on non-customers to make them customers by offering new products.

My organization focuses on non-customers to make them customers by offering new services.

The prices of our products are easily affordable for most of customers.

The prices of our services are easily affordable for most of customers.

\section{Breaking The Value-Cost Trade-offs}

My organization tends to remove all elements in the production processes which are not creating any value to the product.

My organization tends to remove all elements in the processes which are not creating any value to the service.

My organization tends to reduce all elements in the production processes which are not creating much value to the product. 
My organization tends to reduce all elements in the processes which are not creating much value to the service.

My organization tends to improve the processes which are creating innovation to the product.

My organization tends to improve the processes which are creating innovation to the service.

My organization focuses on creation of new elements that add value to the product which industry has never offered

My organization focuses on creation of new elements that add value to the service which industry has never offered

My organization businesses has exceptional buyer utility for customers.

\section{Achieving Differentiation and Low Cost}

My organization focuses on creating differentiation to attract customers

My organization focuses on cost reduction to attract new customers

My organization aligns the whole system of its activities in pursuit of differentiation.

My organization aligns the whole system of its activities in pursuit of cost. 